
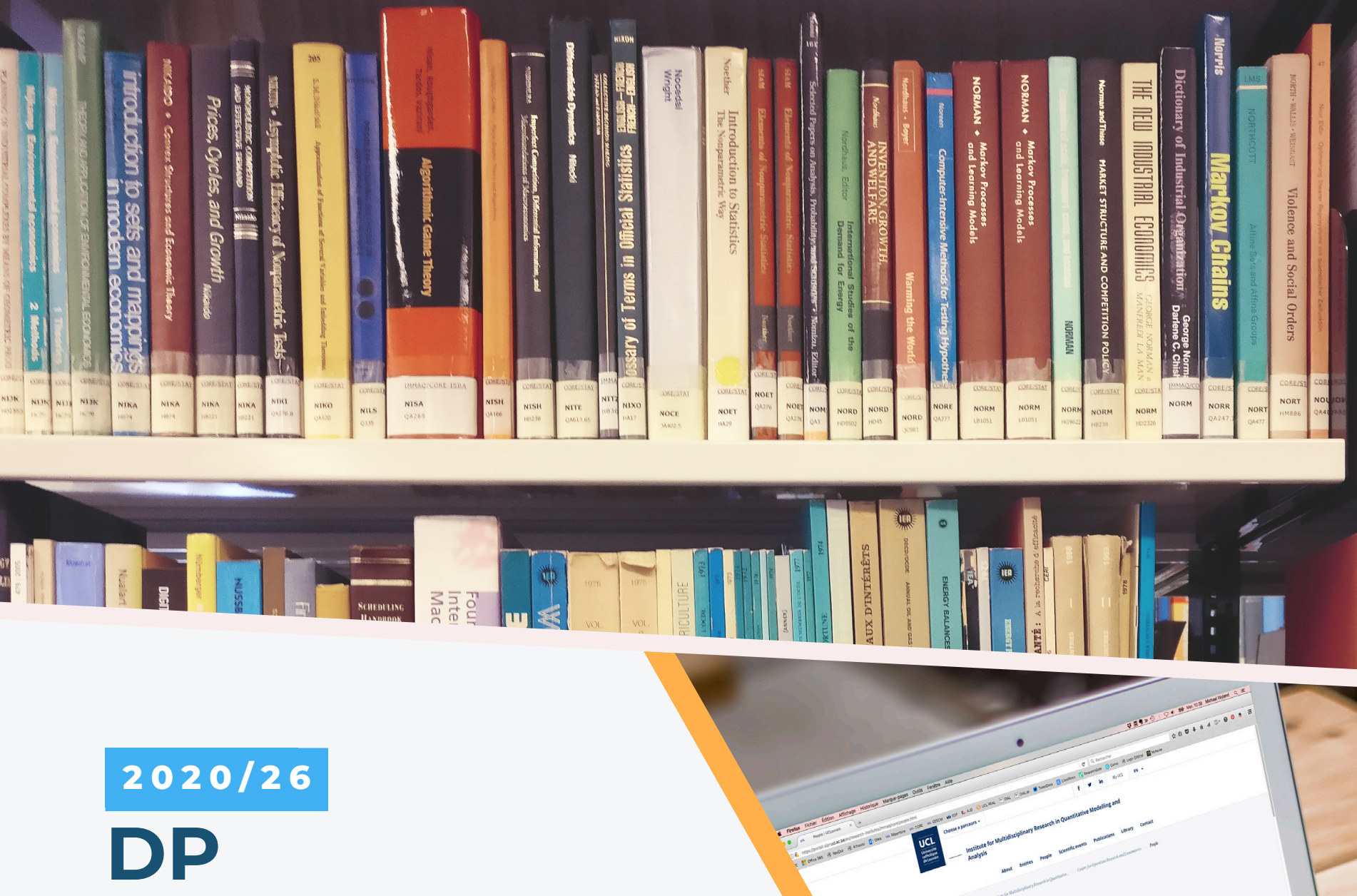

Yurii Nesterov

Populism and social

polarization in European

democracies 


\section{CORE}

Voie du Roman Pays 34, L1.03.01

B-1348 Louvain-la-Neuve

Tel (32 10) 474304

Email: immaq-library@uclouvain.be

https://uclouvain.be/en/research-institutes/

lidam/core/discussion-papers.html 


\title{
Populism and Social Polarization in European Democracies ${ }^{1}$
}

\author{
Victor Ginsburgh \\ ECARES, Université libre de Bruxelles \\ and CORE, Université catholique de Louvain \\ Sergio Perelman \\ Université de Liège \\ Pierre Pestieau \\ CORE, Université catholique de Louvain \\ and Université de Liège
}

July 14,2020

\begin{abstract}
The objective of this paper is to explain populist attitudes that are prevailing in a number of European democracies. Populist attitudes expectedly lead to social protests and populist votes. We capture the populist wave by relying not on voting behavior but rather on values that are traditionally viewed as populist values, such as distrust of institutions and neighbors, rejection of migrations and strong preferences for law and order. Our study covers the period 2004 to 2018 and 25 European countries for which we match aggregated indicators of populist values and social polarization computed from ESS and SILC survey micro-data, respectively. We find that social polarization, along with other factors, can explain populist attitudes. We also observe that both populist attitudes and polarization vary across countries much more than over time, with the exception of authoritarian values which appear positively correlated with social polarization, particularly among baby-boomers and younger cohorts.
\end{abstract}

Keywords: populism, polarization, social divide

JEL codes: D63, I30

\footnotetext{
${ }^{1}$ The authors would like to thank Eurostat for providing access to SILC Micro-data. The views they express in this document do not reflect the views of Eurostat, nor those of the European Commission or the national authorities who let us access to the data. We are also grateful to Shlomo Weber for his insights on the measurement of polarization.
} 


\section{Introduction}

During the last 15 years, two perceived parallel evolutions could be observed: Mounting populist waves and widening social divides. We show that these evolutions were a matter of perception much more than of reality, a perception that was conveyed by resounding elections of populist characters (Bolsonaro in Brazil, Trump in the US, Orban in Hungary, and others), accompanied by upsurges of social protests such as the Gilets Jaunes in France, that received a wide coverage in the media. When looking at hard facts, we observe that indeed populist attitudes as well as social divides prevail in most countries and that both phenomena are closely related, though their extent reveals to be quite stable over time but varies to a great extent across countries.

Throughout the paper, we capture the populist wave by relying not on voting behavior but rather on values that are traditionally viewed as populist values, such as distrust of institutions and neighbors, rejection of migrations and strong preferences for law and order. These values, for which there exists good evidence in a large number of European countries during 15 years (2004-2018), are collected. Social divides are measured using the index of polarization introduced by Esteban and Ray $(1991,1994,2011)$, a measure that is often applied in political science to study conflicts.

A couple of words on these choices are in order. First, we choose to explain populist attitudes rather than populist votes because evidence on populist votes lacks consistency and homogeneity; it pertains to very different elections (local, regional, national and even European) and the definition of populist parties is often questionable and changing. Second, traditional measures of inequality and poverty do not capture well the complex reality of social divides and particularly the tensions between the middle class and both the lower and the upper tail of the income distribution. Polarization indicators do reflect such reality.

Our approach is at odds with the usual approach that relates the populist vote to factors such as globalization, cost of living increase, immigration or unemployment. It is closer to the work by Norris and Inglehart (2018) who use the European Social Survey (ESS) data to explain populist vote and authoritarian/ libertarian values with generational differences and cultural backlash, as main factors. We use the same data set but focus on social polarization as possible argument for populist attitudes.

To be clear, there are four possible variables (or groups of variables) that are important: (a) populist votes, (b) populist attitudes and values, (c) social divides and (d) a number of economic factors. In this paper, we look at the effect of (c) on (b), while most of the literature focuses on the effect of one or several variables listed in (d) on (a).

This literature explains reasons for populist votes with factors such as prolonged lack of income growth, combined with massive growth at the top of the income distribution; an education system that limits the opportunities of children from modest parental backgrounds; 
outsourcing of 'good' jobs to China and other emerging economies; technological change that has made many 'routine' middle-class jobs redundant. A couple of examples follow. ${ }^{2}$

Using seventeen years of the German Socio-Economic Panel, Geishecker and Siedler (2012) examine whether job-loss fears impact on individuals' party identification. They find strong and robust evidence that subjective job-loss fears foster affinity for parties at the far rightwing of the political spectrum. Becker et al. (2017) find that the 2016 Brexit referendum result in the United Kingdom is strongly correlated with various characteristics of voters across the 380 local authority areas. Having few or no qualification, living in areas with a strong tradition of manufacturing employment or with a high number of migrants from the twelve EU accession countries could be a strong predictor of the Brexit vote. Autor et al. (2016) study the populist vote in the 2016 American presidential elections. As they show, growing import competition from China has contributed to a shift in congressional voting toward ideological extremes. In a study based on regional data for 14 Western European Countries over the period 1993 to 2016, Anelli et al. (2019) find that higher robotization exposure may lead to increasing support for national and radical right parties. In his analysis of populism across Europe and America, Rodrick (2017) shows that throughout history waves of globalisation are prone to populist backlashes. Algan et al. (2017) tries to explain the Front National vote during the recent French presidential election. According to this research, a sense of deteriorating wellbeing is one of the main explanations of the rising support for the FN, cutting across most boundaries of age, education, or economic status. In a recent study, Bordingnon et al. (2019) analyze municipalities' data in a Northern Italian region, Lombardia and conclude that "the share of immigrants follows a U-shaped curve which exhibits a tipping-like behavior around a share of immigrants equal to $3.35 \%$."

Anticipating the results of the paper, we show that differences in polarization across 25 European countries are correlated with differences in populist attitudes. However, we also observe large variations across countries, but no upward time trend in the relation, though this is usually thought to be the case. The only exception are authoritarian values which appear positively correlated with social polarization, particularly among baby-boomers and younger cohorts.

The paper is organized as follows. In section 2, we discuss our main variables, namely populist attitudes and polarization and show how they differ across countries and over time. In section 3, we test the relation between populist attitudes, the degree of social polarization and covariates, such as the stock and the flow of migrants from less developed countries. We conclude in Section 4.

\footnotetext{
${ }^{2}$ See also Lefebvre and Pestieau (2018).
} 


\section{Social divides and populist attitudes}

\subsection{Data}

To study the link between populist attitudes and behavior, and social divides, we rely on two large European surveys, SILC (Eurostat, 2020) and ESS (European Social Survey, 2020).

SILC microdata are used to compute polarization indices that describe the possible fractures of living conditions across income classes. SILC is an annual survey that started in 2004 and includes data on economic and living conditions, in particular on the disposable income of households. The sample is representative of the population aged 16 years plus.

ESS data come in to compute several indicators related to individual populist attitudes and voting behavior. The survey started in 2002, but collect data during even years only. Some parts (or modules) are repeated every even year, others are more occasional, in some cases, unique. ESS aims at collecting changes in individual 'attitudes, beliefs and behavior patterns' including political orientation and parties for which individuals voted in the last election that preceded the year in which the survey was taken. The sample is representative of the population aged 18 years plus.

We combine the information available from both surveys, and aggregate at the level of countries and years, implicitly assuming that both samples, randomly chosen from the same population, are representative. Appendix Table A1, describes which data are available by country and years. Given that ESS runs its surveys every even year while SILC started in most countries for every year in 2005 , the final panel includes 25 countries, eight years (2004 to 2018 , even years only), but only 157 data points ${ }^{3}$ instead of $25 * 8=200$, since some countries are missing, especially in $2004 .{ }^{4}$ With the exception of Greece, Italy, and Iceland, all countries are present at least five times out of eight, but the panel is obviously unbalanced.

\subsection{Populist attitudes}

Political scientists use two types of variables to address the issue of populism: (a) Votes or membership participation to populist parties or (b) values and attitudes, which can be considered supporting or related to populist behavior. We chose option (b) for the reason that evidence on populist values is much more reliable than voting behavior: interviewees often do not remember the vote they cast, or feel uncomfortable to confess they voted for a populist party or personality, and others simply did not vote, up to near $30 \%$ in many countries, as we learn from ESS in figures reported in Table A2 in the Appendix.

We follow Norris and Inglehart (2018), who introduced indicators of 'distrust of institutions', 'anti-immigration feelings' and 'leaning for law and orders' (authoritarianism) in their work. These are computed using ESS individuals' answers to specific questions. We added a fourth

\footnotetext{
${ }^{3}$ For some analyses, only 152 observations are available.

${ }^{4}$ On average, SILC's sample size is almost ten times as large as ESS's. To keep indicators comparable across both surveys, we use specific weights variables, provided by ESS and SILC, to correct for sampling bias. See footnotes in Tables A3 and A4, respectively.
} 
indicator reflecting 'distrust of people', which also prevails in populist behavior (Olivera, 2014). Appendix Table A3 displays the questions used. For each indicator and each individual, we added the scores given as answers to the corresponding questions, and normalized them within the range 0 to 100 . A summary by country over three periods (20042008, 2010-2014 and 2016-2018) is available in Table 1. Countries are classified in four homogenous groups. As can be observed, there are large variations with and within each subgroup depending on the indicator at hand. But more importantly, and contrary to what is usually assumed, there are no clear time trends.

\section{[Insert Table 1]}

As already mentioned, voting data lack consistency. Nevertheless, we used the ESS sample to obtain some evidence that extreme right voting and abstentions are positively related to distrust of institutions, anti-immigration attitudes, authoritarianism and distrust of people, by running logistic regressions in which the dependent variables (extreme right voting results or abstentions takes values 0 or 1). Results are shown in Table 2.

\section{[Insert Table 2]}

Both votes for extreme right parties and abstentions may reflect a rejection of the political system, are well positively related to each populist attitude. The only puzzling result is the negative effect of authoritarianism on abstentions in the last two columns of the Table 2. In each case, the same analysis was run controlling for heterogeneity across countries and years and the results are relatively stable. The estimated parameters changed in most cases but neither their sign, nor their statistical significance. ${ }^{5}$

\subsection{Social polarization}

Income inequality and poverty measures are often used to obtain a picture of the state of a society. But it has become increasingly clear that these measures do not reflect the feeling of being left behind that characterizes the lower middle class and that fuels political and social instability in a number of ways. First, increasing 'social barriers' between groups implies that individuals feel less familiar with and connect less to other people. Secondly, it is difficult to develop trust in others as they are seen to have unfair advantages. Finally, unequal communities may disagree over how to share (and finance) public goods, and those disagreements can turn breaking social ties and lessen social cohesion. Broken trust leads to intolerance and discrimination. To assess these social divides, we assumed that simple poverty measures are insufficient, and we resorted to polarization measures that have been widely used to analyze ethnic conflicts and linguistic differences. Based on a recent study by OECD (2019), we postulate that a polarization process is at work in European societies and that it is possible to measure it making the distinction between three main income categories within the population, low-income, middle-income and upper-income classes, on the basis of their relative position to a country's median income. As shown in this OECD study, the

\footnotetext{
${ }^{5}$ See also Appendix Table A3 for voting results.
} 
middle-class is under pressure, particularly in Western industrialized countries, where simultaneously the increasing cost of life and job insecurity impact their living conditions and reduce their social mobility opportunities. ${ }^{6}$

The idea of polarization can be described using a certain number of steps. Assume that we have a given exogenous partition into income groups $j$ and $k, n_{i, j}$ and $n_{i, k}$ in country $i$. Income 'diversity' can then be defined by $\sum_{j} \sum_{k} n_{i, j} . n_{i, k}, j \neq k .{ }^{7}$ If, in addition, one can estimate distances $\delta_{i, j k}$ measured by, say the 'ability to make ends meet' between groups $j$ and $k$, then 'distance weighted diversity' can be written as $\sum_{j} \sum_{k} n_{i, j} . n_{i, k} . \delta_{i, j k}$. Esteban and Ray's (2011) formulation of polarization is very close to diversity, but they include a parameter $(1+\theta)$, $\theta \in[0,1.6]$, which expresses the fact that group $i$ puts a larger weight (for instance in terms of confidence) on those of the same group than on other ones, or are more antagonistic to those who do not belong to their own group: $p_{i}=\sum_{j} \sum_{k} n_{i, j}^{1+\theta} \cdot n_{i, k} \cdot \delta_{i, j k}$.

To obtain the polarization index $p_{i t}^{S}$ that will be used in our paper, we simply add in the last expression a subscript $t$ for time (years from 2004 to 2018) and a superscript $s$ for each of two types of distances between groups that will now be used:

$$
p_{i t}^{S}=\sum_{j} \sum_{k} n_{i t, j}^{1+\theta} n_{i t, k} . \delta_{i t, j k}^{S}, \text { with } \theta \in[0,1.6] .
$$

Using SILC microdata and following OECD (2019) definitions, we classify populations in each year and country, as follows: Middle-income group involves individuals in households with disposable income (standardized using the OECD equivalence scale) between 0.75 and twice the median standardized disposable income. The lower-income group contains those individuals in households with disposable income less than $3 / 4$ of the median disposable income. The upper-income group contains those whose income is larger than twice the median disposable income.

SILC microdata also allows computing two types of distances which reflect living conditions gaps across income classes. First, a subjective measure based on the answer given by the households' reference individual, on her/his 'ability to make ends meet.' The answer is qualitative and goes from 'with great difficulty' to 'very easily' on a scale from 1 to 6 . For each income group, we take the percentage of individuals with score 1 ('with great difficulty') or 2 (with 'difficulty'). Secondly, we use a so-called 'material deprivation index' (Townsend, 1979) which corresponds to the addition of binary answers (yes or no) to a battery of SILC questions. Their precise formulation can be found in Appendix Table A4, which also contains questions that make it possible to compute Townsend's deprivation index (see also Verbunt and Guio, 2019). For each income group, we take the average percentage of individuals who cannot afford two or more of these items.

\footnotetext{
${ }^{6}$ On diminishing social mobility, see OECD (2018).

${ }^{7}$ Note that this expression is equivalent to the Gini coefficient.
} 
Table 3 provides the distances between the lower and the higher income classes for the 'ability to make ends meet' and for the index of 'deprivation.' The difference between Central and Northern Europe, on the one hand, and Southern and Eastern Europe, on the other, is striking as expected.

\section{[Insert Table 3]}

Regarding identification, Esteban and Ray $(1991,1994)$ show that, under given axioms, the parameter $\theta$ can take values ranging from 0 to 1.6. In what follows, we have chosen the most commonly chosen value of $\theta=1 .^{8}$

Using the above distances and the identification value, we compute polarization indexes with distances based on subjective or material deprivation scores, listed in Table 4.

\section{[Insert Table 4]}

Focusing first on the indices based on the subjective 'ability to make ends meet,' we observe that average polarization increases between 2004 to 2018 in all four groups of countries. Increases are particularly important in Nordic and Central countries. Only Finland and Iceland experience a decline in polarization. For the two other subgroups, results are mixed. In Southern countries, Italy and Greece polarization decreases. In Eastern Europe, Czechia, Estonia and Poland happen also to become less polarized.

The pattern is somewhat different for 'deprivation scores.' On average, indices are quite stable over time in all regions, with the exception of Southern Europe. They also tend to be higher in Southern and Eastern countries than in the two other subgroups. There are, however, some countries (Austria, France, Denmark, Finland, Czech Republic and Estonia) in which polarization decreases. All in all, there is no clear pattern in this case, but this is also so for populist attitudes. We now turn to the main part of this paper, namely the relation between those two sets of variables.

\section{Polarization and populist attitudes}

In this section we present the results of OLS estimates of the following (unbalanced panel of countries and even years) equation, with 152 or 157 even year*country observations:

$$
y_{i t}^{r}=\alpha^{r, s}+\beta^{r, s} p_{i t}^{s}+\sum_{m} \gamma_{m}^{r, s} x_{i t}^{m}+\varepsilon_{i t}^{r, s}, \forall r, \forall s
$$

where $y_{i t}^{r}$, the left-hand side variable, is one of the four aggregated populist attitudes' (superscript $r$ ), described in Table $1 ; i$ and $t$ represent the country and the year. The righthand side variable, $p_{i t}^{s}$, is one of the two polarization indices based on 'ability to make ends

\footnotetext{
8 This is also the choice made in the conflict or polarization literature. See See Montalvo and Reynal-Querol (2005) and Desmet, Ortuño-Ortín, and Weber (2017). Using additional axioms, Geng (2012) later showed that the range can be shrunk to a single point $\theta=1$ to obtain the Reynal-Querol functional form.
} 
meet' or 'deprivation'. The variables $x_{i t}^{m}$ are five covariates: immigration stock from less developed countries (as a share of total population of the country), and its change over the five last years, GDP per capita, and its change over the five last years, urban population (the share of total population of the country); $\alpha^{r, s}, \beta^{r, s}$ and $\gamma_{m}^{r, s}$ are parameters to be estimated and $\varepsilon_{i t}^{r, s}$ is the error term. ${ }^{9}$

The OLS estimates for the four populist attitudes indicators are displayed in Table 5. In all four regressions (where the left-hand side distrust of institutions, anti-immigration, authoritarianism and distrust of people) the polarization index picks up a coefficient that is positive and statistically different from 0 at the one percent level in all cases. Immigration has a negative effect on populist attitudes, but the coefficient is significantly different from 0 for authoritarianism only. The five-year change in immigration picks up a coefficient that is significantly positive, but is very small, so that the effect of the two immigration variables remains negative. The level of GDP as well as its increase over the last five years pick up a negative effect on populism when significant, which is expected. The coefficient of the relative importance of the urban population is consistently negative: urban areas are more prone to accept immigrants than rural areas.

To summarize, polarization is always positively correlated with $y_{i t}^{r}$; the immigration stock and its change have little explanatory power; a larger GDP and a larger share of urban population both have negative effects. The R-squares are reasonable, with the exception of the anti-immigration populist attitude, which goes against what one is often suggested concerning immigration.

\section{[Insert Table 5]}

We also ran OLS regressions identical to those in Table 5 that aim at estimating within countries OLS coefficients and at the same time correct the potential bias due to unobserved heterogeneity. As indicated before, no clear path was observed when examining descriptive statistics, neither in populism values, nor in polarization. This observation is confirmed for three over four populist attitudes under study. The only notable exception is for the case of authoritarianism and for the polarization index based on 'ability to make ends meet' distance. The first column in Table 6 reports the results obtained for whole population samples and the other columns those obtained when dividing the population in three cohorts: born before 1946, born between 1946 and 1974 and born after 1974. The coefficients in Table 6 are largely consistent with cross-section coefficients reported in Table 5 for authoritarianism. The

\footnotetext{
${ }^{9}$ GDP per capita and the rate of urbanization are taken from WDI (2020). For the computation of the immigration stock we rely on detailed cross-country migration data from the United Nations Population Division (UN, 2020). For each of the 25 European countries, we computed the net immigration stock of people who were born in less developed countries. Given that the information is available every five years only, we interpolated the immigration stock for missing years. We use the ratio between the immigration stock and total population (WDI, 2020) in our estimations.
} 
only exception is for the oldest cohort, born before 1946 and for the effect of the immigration stock, the sign of which is now positive and highly significant. ${ }^{10}$

\section{[Insert Table 6]}

These results confirm the role of social polarization aside immigration, economic growth and urbanisation in the formation of authoritarian values. As we show in Table 2, authoritarianism is significantly positive on extreme right-wing vote but negative on vote abstention. To some extent, these results are in line with those reported by Norris and Inglehart (2018, Chapter 6). For these authors, authoritarian values are the main driver of populist votes in European countries, but they identify authoritarianism in relation with older cohorts. In our case, also European countries observed over the last fifteen years, authoritarianism appears as a value driven by social polarization and immigration but, on the contrary, mainly among babyboomers and younger cohorts.

\section{Conclusions}

Our aim was to explain populist attitudes (that may eventually lead to populist votes) by a number of factors, the most important being the degree of social polarization, which measures the extent of social divides that plague our societies. Polarization is significantly positive correlated with all four populist attitudes but particularly on authoritarianism. To our knowledge this is the first attempt to correlate populism using such indicators of polarization that reflect the socio-economic divides that plague Europe better than standard measures of inequality or poverty.

\section{References}

Algan, Y., E. Beasley, M. Foucault and P. Vertie (2017). Bien-être et Vote. Observatoire du Bien-être du CEPREMAAP, 2017-02.

Anelli, M, I. Colantone and P. Stanig (2019). We Were the Robots: Automation and Voting behavior in Western Europe. IZA Working Paper 12485.

Autor, D., D. Don, G. Hanson and K. Majlesi (2016). Importing Political Polarization? The Electoral Consequences of Rising Trade Exposure. NBER Working Paper 22637.

Becker, S., T. Fetzer, and D. Novy (2017). Who Voted for Brexit? CESIfo Discussion Paper 1480.

\footnotetext{
${ }^{10} \mathrm{We}$ also estimated for each cohort separately the same models as in Table 5, without country dummies. Table A5 in Appendix reports the results obtained with polarization indexes based on 'ability to make ends meet'. They are consistent with those reported in Table 5, though older cohorts are less polarized than younger ones, in their distrust towards institutions, but more polarized in their distrust towards other people. Otherwise, the latest cohort, born after 1974, appears as less sensitive to immigration.
} 
Bordingnon, M., M. Gamalerio, E. Slerca and G. Turati (2019). Stop Invasion! The Electoral Tipping in Anti-immigrant Voting. IEB Working Paper 2019/11.

Chapel Hill Expert Survey (2019). https://www.chesdata.eu/2019-chapel-hill-expert-survey

Esteban, J. and D. Ray (1991). On the Measurement of Polarization. Working Paper 18, Boston University, Institute for Economic Development.

Esteban, J. and D. Ray (1994). On the Measurement of Polarization. Econometrica, 62: 819852.

Esteban, J. and D. Ray (2011). Linking Conflict to Inequality and Polarization. American Economic Review, 101: 1345-1374.

European Social Survey (ESS) (2020). https://www.europeansocialsurvey.org.

Eurostat (2020). Survey on Income and Living Conditions, Microdata. https://ec.europa.eu/eurostat/web/microdata/statistics-on-income-and-living-conditions.

Geishecker, I. and T. Siedler (2012). Job Loss Fears and (Extremist) Party Identification: First Evidence from Panel Data. IZA Discussion Paper 6996.

Geng, D. (2012). Identifying the Unique Polarization Index: A Mean-Preserving Axiomatic Approach. Journal of Public Economic Theory 14: 791-812.

Lefèbvre M. and P. Pestieau (2018). The Welfare State in Europe. Oxford: Oxford University Press.

Montalvo, J. and M. Reynal-Querol (2005). Ethnic Polarization, Potential Conflict, and Civil Wars. American Economic Review 95: 796-816.

Norris P. and R. Inglehart (2018). Cultural Backlash: Trump, Brexit and Authoritarian Populism. New York: Cambridge University Press.

OECD (2017). Understanding the Socio-economic Divide in Europe, Background Report. https://www.oecd.org/els/soc/cope-divide-europe-2017-background-report.pdf

OECD (2018). A Broken Social Elevator? How to Promote Social Mobility. Paris: OECD Publishing. http://dx.doi.org/10.1787/9789264301085-en

OECD (2019). Under Pressure: The Squeezed Middle Class. Paris: OECD Publishing. https://doi.org/10.1787/689afed1-en 
Olivera, J. (2014). Changes in Inequality and Generalized Trust in Europe. Social Indicators Research 124: 21-41.

Reynal-Querol, M. (2002). Ethnicity, Political Systems, and Civil Wars. Journal of Conflict Resolution 46: 29-54.

Rodrik, D. (2017). Populism and the Economics of Globalization. Cambridge, MA: Harvard University Press.

Townsend, P. (1979). Poverty in the United Kingdom. London: Allen Lane and Penguin Books.

UN (2020). International Migrants Stock, United Nations, Population Division. https://www.un.org/en/development/desa/population/migration/data/

Verbunt, P. and A.-C. Guio (2019), Explaining Differences Within and Between Countries in the Risk of Income Poverty and Severe Material Deprivation: Comparing Single and Multilevel Analyses. Social Indicators Research, 144:2, 827-868.

WDI (2020). World Development Indicators, Washington: The World Bank. https://databank.worldbank.org/source/world-development-indicators. 
Table 1. Populist attitudes by region country and period

\begin{tabular}{|c|c|c|c|c|c|c|c|c|c|c|c|c|c|}
\hline \multirow{2}{*}{ Region } & \multirow{2}{*}{ Country } & \multicolumn{3}{|c|}{ Distrust of institutions } & \multicolumn{3}{|c|}{ Anti-immigration } & \multicolumn{3}{|c|}{ Authoritarianism } & \multicolumn{3}{|c|}{ Distrust of people } \\
\hline & & $2004-08$ & $2010-14$ & 2016-18 & 2004-08 & $2010-14$ & 2016-18 & $2004-08$ & $2010-14$ & $2016-18$ & $2004-08$ & $2010-14$ & $2016-18$ \\
\hline \multirow{7}{*}{ Central } & Austria & 61.0 & 60.7 & 55.5 & 51.6 & 51.4 & 51.5 & 63.9 & 71.1 & 70.0 & 46.0 & 46.7 & 42.3 \\
\hline & Belgium & 56.4 & 57.1 & 57.1 & 50.5 & 50.7 & 46.2 & 66.6 & 66.9 & 66.1 & 49.5 & 48.7 & 47.5 \\
\hline & France & 63.2 & 66.2 & 66.5 & 51.3 & 52.0 & 48.8 & 58.4 & 59.4 & 59.8 & 51.1 & 50.6 & 49.1 \\
\hline & Germany & 63.4 & 60.1 & 56.6 & 49.0 & 44.0 & 43.3 & 63.2 & 64.9 & 62.6 & 48.4 & 47.0 & 44.1 \\
\hline & Ireland & 60.5 & 67.0 & 59.5 & 43.0 & 47.9 & 38.5 & 68.5 & 68.7 & 67.0 & 41.4 & 43.6 & 40.8 \\
\hline & Switzerland & 49.1 & 46.0 & 43.5 & 42.4 & 41.2 & 40.4 & 62.1 & 66.3 & 64.1 & 41.0 & 41.2 & 39.1 \\
\hline & United Kingdom & 61.9 & 62.1 & 60.7 & 52.9 & 51.4 & 41.1 & 64.9 & 67.0 & 63.1 & 44.7 & 44.0 & 44.0 \\
\hline \multirow{5}{*}{ Southern } & Cyprus & 52.2 & 67.8 & 71.0 & 58.0 & 65.9 & 56.8 & 76.7 & 78.4 & 75.1 & 54.9 & 61.8 & 60.4 \\
\hline & Greece & 65.6 & 83.8 & - & 64.4 & 70.0 & - & 79.8 & 77.2 & - & 64.0 & 62.7 & - \\
\hline & Italy & - & 77.0 & 70.4 & - & 51.2 & 57.9 & - & 75.7 & 72.9 & - & 54.1 & 54.3 \\
\hline & Portugal & 72.5 & 77.2 & 69.3 & 52.7 & 53.2 & 41.2 & 65.0 & 64.9 & 60.5 & 57.6 & 57.7 & 54.8 \\
\hline & Spain & 59.8 & 72.1 & 70.4 & 45.2 & 45.1 & 41.0 & 73.0 & 71.1 & 70.1 & 50.8 & 50.0 & 50.0 \\
\hline \multirow{6}{*}{ Northern } & Denmark & 41.9 & 46.9 & - & 45.2 & 44.6 & - & 62.9 & 64.9 & - & 33.2 & 33.3 & - \\
\hline & Finland & 47.1 & 50.4 & 49.2 & 40.1 & 41.1 & 40.3 & 64.7 & 64.5 & 63.6 & 36.5 & 35.9 & 33.7 \\
\hline & Iceland & 47.7 & 61.7 & 55.4 & 37.7 & 36.2 & 30.0 & 56.9 & 57.0 & 55.7 & 36.0 & 36.8 & 34.4 \\
\hline & Netherlands & 48.9 & 48.3 & 46.6 & 46.2 & 44.7 & 43.4 & 63.8 & 63.7 & 61.3 & 41.4 & 39.9 & 38.8 \\
\hline & Norway & 52.7 & 45.1 & 42.8 & 46.7 & 43.4 & 42.0 & 63.6 & 64.4 & 64.6 & 34.9 & 34.8 & 33.8 \\
\hline & Sweden & 51.2 & 46.7 & 47.8 & 38.2 & 35.4 & 36.3 & 55.7 & 57.2 & 57.4 & 37.1 & 37.3 & 36.9 \\
\hline \multirow{7}{*}{ Eastern } & Czechia & 70.9 & 69.8 & 62.0 & 56.5 & 60.0 & 62.1 & 68.3 & 69.9 & 68.7 & 53.6 & 53.1 & 49.4 \\
\hline & Estonia & 64.1 & 63.4 & 59.8 & 54.3 & 49.4 & 52.7 & 64.6 & 66.0 & 63.4 & 47.8 & 45.0 & 43.9 \\
\hline & Hungary & 73.7 & 65.6 & 59.3 & 58.0 & 55.6 & 63.7 & 70.9 & 72.5 & 68.5 & 56.8 & 53.4 & 52.7 \\
\hline & Lithuania & - & 72.6 & 67.1 & - & 49.4 & 49.9 & - & 66.1 & 65.4 & - & 50.3 & 50.4 \\
\hline & Poland & 77.3 & 74.9 & 70.1 & 41.6 & 41.3 & 44.4 & 75.4 & 76.6 & 73.9 & 59.5 & 57.4 & 57.1 \\
\hline & Slovakia & 65.0 & 71.0 & 64.7 & 52.3 & 55.5 & 61.1 & 72.8 & 74.7 & 70.7 & 57.3 & 57.8 & 59.8 \\
\hline & Slovenia & 64.2 & 76.1 & 71.9 & 53.6 & 53.2 & 55.3 & 68.8 & 74.6 & 73.8 & 54.8 & 54.0 & 51.5 \\
\hline \multirow{4}{*}{ Regions ${ }^{a}$} & Central & 59.4 & 59.9 & 57.1 & 48.7 & 48.4 & 44.3 & 63.9 & 66.3 & 64.7 & 46.0 & 46.0 & 43.8 \\
\hline & Southern & 61.5 & 72.4 & 70.2 & 52.0 & 54.7 & 46.3 & 71.6 & 71.5 & 68.6 & 54.4 & 56.5 & 55.1 \\
\hline & Northern & 49.5 & 50.4 & 48.4 & 41.8 & 40.2 & 38.4 & 60.9 & 61.4 & 60.5 & 37.2 & 36.9 & 35.5 \\
\hline & Eastern & 69.2 & 70.1 & 64.6 & 52.7 & 52.5 & 56.6 & 70.1 & 72.4 & 69.8 & 55.0 & 53.5 & 52.4 \\
\hline
\end{tabular}

Source: ESS 2004-2018 (all available waves).

Notes: ESS weight variable: pspwght. For Greece, Italy, Denmark and Lithuania, the averages by region and period, exclude countries with incomplete period information. 
Table 2. Voting and populist attitudes. Logistic regressions

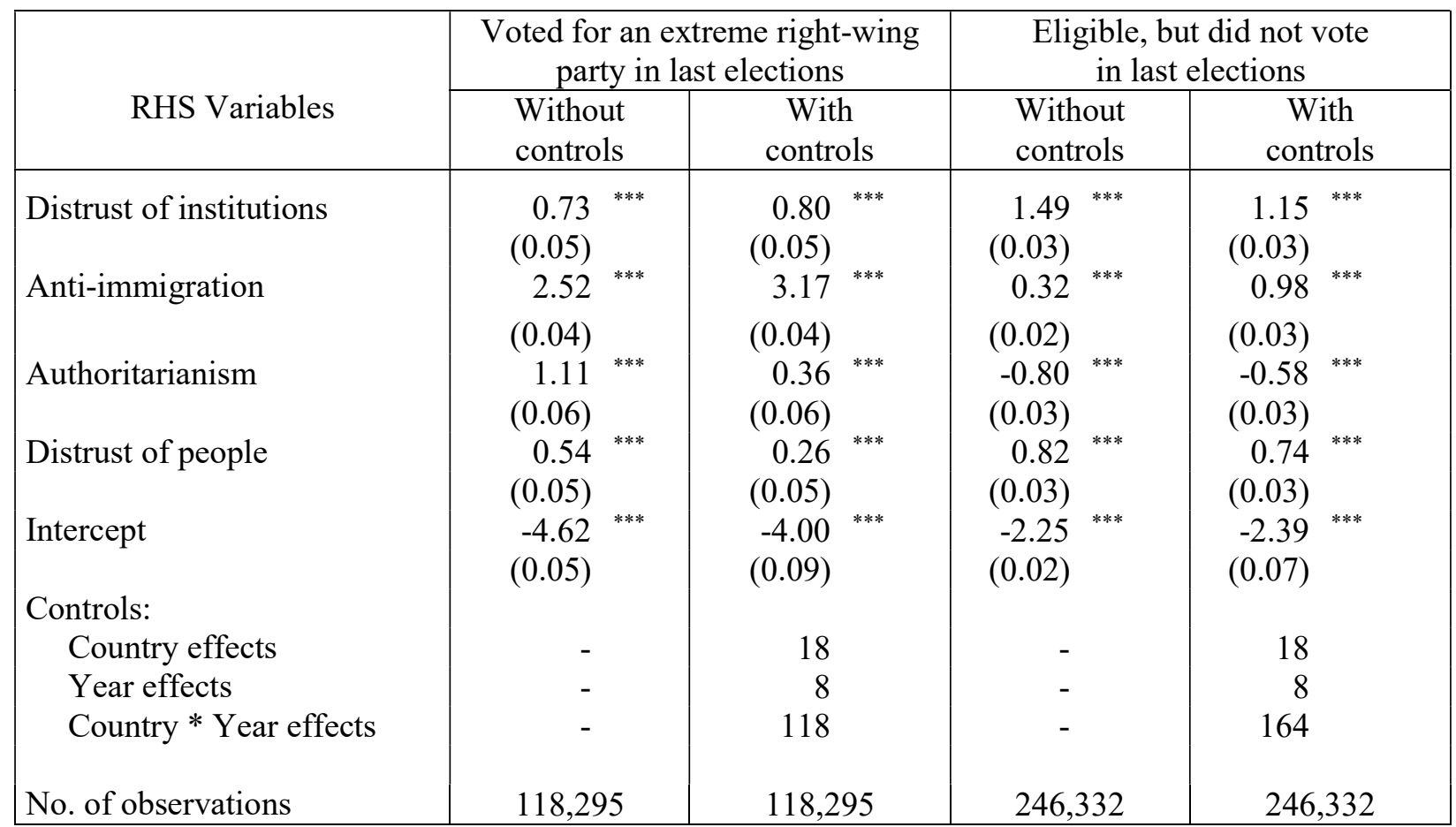

Source: ESS 2004-2018 (all available waves).

ESS weight variable: pspwght.

Note: ${ }^{* *},{ }^{* *},{ }^{*}$ statistically significant at the $1 \%, 5 \%$ and $10 \%$ level, respectively. 
Table 3. Distance between upper-income and low-income classes (in percent)

\begin{tabular}{|c|c|c|c|c|c|c|c|}
\hline \multirow{2}{*}{ Region } & \multirow{2}{*}{ Country } & \multicolumn{3}{|c|}{$\delta=$ Ability to make ends meet } & \multicolumn{3}{|c|}{$\delta=$ Deprivation } \\
\hline & & 2004-08 & $2009-14$ & $2015-18$ & 2004-08 & $2009-14$ & $2015-18$ \\
\hline \multirow{8}{*}{ Central } & Mean & 25.7 & 31.1 & 29.7 & 42.8 & 43.9 & 40.6 \\
\hline & Austria & 18.8 & 27.9 & 25.5 & 40.4 & 38.3 & 32.6 \\
\hline & Belgium & 32.8 & 39.5 & 42.0 & 44.3 & 45.8 & 47.2 \\
\hline & France & 30.9 & 36.0 & 36.4 & 49.7 & 48.6 & 46.7 \\
\hline & Germany & 17.4 & 22.7 & 16.5 & 49.7 & 53.1 & 41.3 \\
\hline & Ireland & 32.4 & 41.7 & 38.8 & 42.2 & 60.0 & 58.2 \\
\hline & Switzerland & 14.6 & 20.7 & 22.8 & 21.7 & 20.1 & 21.8 \\
\hline & United Kingdom & 21.5 & 29.0 & 27.8 & 34.2 & 44.1 & 41.3 \\
\hline \multirow{6}{*}{ Southern } & Mean & 51.3 & 55.6 & 53.7 & 57.7 & 63.7 & 62.2 \\
\hline & Cyprus & 61.7 & 63.6 & 72.3 & 71.7 & 70.5 & 71.7 \\
\hline & Greece & 62.6 & 57.3 & 54.5 & 60.9 & 72.8 & 74.1 \\
\hline & Italy & 48.0 & 52.9 & 45.1 & 46.8 & 55.2 & 50.4 \\
\hline & Portugal & 49.7 & 55.3 & 50.1 & 66.2 & 63.1 & 59.7 \\
\hline & Spain & 36.6 & 49.0 & 46.3 & 45.9 & 57.1 & 55.0 \\
\hline \multirow{7}{*}{ Northern } & Mean & 17.4 & 19.5 & 18.8 & 29.9 & 29.2 & 29.0 \\
\hline & Denmark & 14.1 & 18.6 & 18.8 & 29.7 & 30.2 & 29.1 \\
\hline & Finland & 17.2 & 15.4 & 13.7 & 44.5 & 38.9 & 36.6 \\
\hline & Iceland & 17.9 & 24.7 & 25.0 & 25.2 & 21.5 & 25.1 \\
\hline & Netherlands & 26.3 & 27.6 & 27.7 & 33.5 & 38.1 & 41.6 \\
\hline & Norway & 14.4 & 15.1 & 14.4 & 21.9 & 21.8 & 24.4 \\
\hline & Sweden & 16.2 & 15.8 & 16.4 & 25.6 & 24.9 & 25.2 \\
\hline \multirow{8}{*}{ Eastern } & Mean & 45.0 & 49.7 & 42.0 & 63.6 & 62.6 & 53.1 \\
\hline & Czechia & 49.8 & 50.1 & 39.2 & 64.1 & 63.9 & 48.9 \\
\hline & Estonia & 27.8 & 39.7 & 25.4 & 65.7 & 56.7 & 41.1 \\
\hline & Hungary & 53.2 & 64.8 & 58.3 & 68.4 & 74.2 & 68.2 \\
\hline & Lithuania & 43.3 & 46.2 & 42.5 & 64.2 & 60.1 & 60.1 \\
\hline & Poland & 57.5 & 51.2 & 39.9 & 66.5 & 66.6 & 53.1 \\
\hline & Slovakia & 43.9 & 46.1 & 43.2 & 60.6 & 59.9 & 54.4 \\
\hline & Slovenia & 44.0 & 49.5 & 45.8 & 55.5 & 57.0 & 49.5 \\
\hline
\end{tabular}

Source: SILC 2004-2018 (all available waves).

Notes: Alienation across social classes is measured by using distances between either (a) average percentage of individuals reporting difficulties to make ends meet $(1=$ with great difficulties or $2=$ with difficulties $)$ or (b) average percentage of individuals with material deprivation (cannot afford two or more items). For a more detailed description of the corresponding SILC questions, see Table A4 in Appendix. SILC weight variable: RBO50. 
Table 4. Polarization indices

\begin{tabular}{|l|l|ccc|cccc|}
\hline \multirow{2}{*}{ Region } & \multirow{2}{*}{ Country } & \multicolumn{3}{|c|}{$\delta=$ Ability to make ends meet } & \multicolumn{3}{c|}{$\delta=$ Deprivation } \\
\cline { 2 - 8 } Central & & $2004-08$ & $2009-14$ & $2015-18$ & $2004-08$ & $2009-14$ & $2015-18$ \\
\hline \multirow{5}{*}{ Soun } & 0.035 & 0.040 & 0.041 & 0.057 & 0.057 & 0.056 \\
\cline { 2 - 8 } & Austria & 0.026 & 0.036 & 0.036 & 0.051 & 0.049 & 0.045 \\
& Belgium & 0.048 & 0.057 & 0.064 & 0.063 & 0.068 & 0.075 \\
& France & 0.040 & 0.044 & 0.045 & 0.062 & 0.061 & 0.059 \\
& Germany & 0.024 & 0.034 & 0.026 & 0.066 & 0.076 & 0.064 \\
& Ireland & 0.043 & 0.047 & 0.047 & 0.058 & 0.068 & 0.075 \\
& Switzerland & 0.019 & 0.027 & 0.030 & 0.028 & 0.026 & 0.030 \\
& United Kingdom & 0.028 & 0.037 & 0.036 & 0.045 & 0.054 & 0.052 \\
\hline \multirow{5}{*}{ Northernyyyyyy} & Mean & 0.057 & 0.062 & 0.063 & 0.068 & 0.077 & 0.076 \\
\cline { 2 - 8 } & Cyprus & 0.063 & 0.065 & 0.080 & 0.079 & 0.078 & 0.083 \\
& Greece & 0.066 & 0.057 & 0.052 & 0.072 & 0.093 & 0.085 \\
& Italy & 0.059 & 0.065 & 0.060 & 0.062 & 0.069 & 0.067 \\
& Portugal & 0.058 & 0.064 & 0.062 & 0.074 & 0.071 & 0.073 \\
& Spain & 0.042 & 0.060 & 0.061 & 0.056 & 0.072 & 0.075 \\
\hline & Mean & 0.022 & 0.025 & 0.026 & 0.040 & 0.040 & 0.041 \\
\cline { 2 - 8 } & Denmark & 0.020 & 0.025 & 0.025 & 0.042 & 0.041 & 0.039 \\
& Finland & 0.025 & 0.022 & 0.018 & 0.063 & 0.057 & 0.052 \\
& Iceland & 0.019 & 0.023 & 0.024 & 0.028 & 0.023 & 0.028 \\
& Netherlands & 0.031 & 0.035 & 0.040 & 0.042 & 0.050 & 0.059 \\
& Norway & 0.019 & 0.021 & 0.021 & 0.030 & 0.031 & 0.036 \\
& Sweden & 0.021 & 0.023 & 0.026 & 0.035 & 0.039 & 0.041 \\
\hline \multirow{5}{*}{ Eastern } & Mean & 0.052 & 0.056 & 0.052 & 0.066 & 0.067 & 0.064 \\
\cline { 2 - 7 } & Czechia & 0.054 & 0.050 & 0.045 & 0.066 & 0.063 & 0.057 \\
& Estonia & 0.041 & 0.055 & 0.038 & 0.078 & 0.071 & 0.058 \\
& Hungary & 0.055 & 0.065 & 0.064 & 0.060 & 0.067 & 0.076 \\
& Lithuania & 0.057 & 0.056 & 0.058 & 0.073 & 0.068 & 0.077 \\
& Poland & 0.066 & 0.064 & 0.053 & 0.067 & 0.075 & 0.067 \\
& Slovakia & 0.046 & 0.050 & 0.046 & 0.051 & 0.061 & 0.053 \\
& Slovenia & 0.049 & 0.056 & 0.058 & 0.062 & 0.067 & 0.065 \\
\hline
\end{tabular}

Source: SILC 2004-2018 (all available waves). 
Table 5. Populist attitudes, polarization and covariates. OLS regressions

\begin{tabular}{|c|c|c|c|c|c|c|}
\hline RHS Variables & $\begin{array}{l}\text { Distrust of } \\
\text { institutions }\end{array}$ & Anti-immigration & \multicolumn{2}{|c|}{ Authoritarianism } & \multicolumn{2}{|c|}{$\begin{array}{c}\text { Distrust of } \\
\text { people }\end{array}$} \\
\hline \multicolumn{7}{|c|}{ Polarization index: $\delta=$ Ability to make ends meet } \\
\hline Polarization index & $\begin{array}{rl}2.225 & * * * \\
(6.1) & \end{array}$ & $\begin{array}{l}1.834 * * * \\
(4.2)\end{array}$ & $\begin{array}{r}2.057 \\
(7.8)\end{array}$ & & $\begin{array}{r}2.920 \\
(11.1)\end{array}$ & $* * *$ \\
\hline Immigration stock & $\begin{array}{r}-0.038 \\
-033)\end{array}$ & 0.175 & $\begin{array}{r}-0.190 \\
(-2.0)\end{array}$ & $* *$ & $\begin{array}{r}-0.054 \\
(-0.6)\end{array}$ & \\
\hline$\Delta$ Immigration stock (5-year lag) & $\begin{array}{r}-0.014 \\
(-0.8)\end{array}$ & $\begin{array}{r}0.009 \\
(0.5)\end{array}$ & $\begin{array}{r}0.038 \\
(3.1)\end{array}$ & $* * *$ & $\begin{array}{r}0.016 \\
(1.3)\end{array}$ & \\
\hline GDP per capita & $\begin{array}{l}-0.1499^{* * *} \\
(-6.4)\end{array}$ & $\begin{array}{r}-0.049 * \\
(-1.8)\end{array}$ & $\begin{array}{r}0.022 \\
(1.3)\end{array}$ & & $\begin{array}{r}-0.075 \\
(-4.5)\end{array}$ & $* * *$ \\
\hline$\Delta$ GDP per capita (5-year lag) & $\begin{array}{l}-0.172 * * * \\
(-4.0)\end{array}$ & $\begin{array}{r}-0.066 \\
(-1.3)\end{array}$ & $\begin{array}{r}0.003 \\
(0.1)\end{array}$ & & $\begin{array}{r}0.002 \\
(0.1)\end{array}$ & \\
\hline Urban population & $\begin{array}{l}-0.179 * * * \\
(-5.7)\end{array}$ & $\begin{array}{r}-0.060 \\
(-1.6)\end{array}$ & $\begin{array}{r}-0.124 \\
(-5.4)\end{array}$ & $* * *$ & $\begin{array}{r}-0.092 \\
(-4.1)\end{array}$ & $* * *$ \\
\hline Intercept & $\begin{array}{l}1.008 * * * \\
(10.5)\end{array}$ & $\begin{array}{l}0.557 * * * \\
(4.9)\end{array}$ & $\begin{array}{r}0.468 \\
(6.8)\end{array}$ & $* * *$ & $\begin{array}{r}0.582 \\
(8.4)\end{array}$ & $* * *$ \\
\hline $\mathrm{R}^{2}$ & 0.747 & 0.342 & 0.551 & & 0.791 & \\
\hline Observations & 157 & 157 & 157 & & 157 & \\
\hline \multicolumn{7}{|c|}{ Polarization index: $\delta=$ Deprivation } \\
\hline Polarization index & $\begin{array}{rl}2.175 & * * * \\
(5.8) & \end{array}$ & $\begin{array}{l}1.587 * * * \\
(3.5)\end{array}$ & $\begin{array}{r}1.471 \\
(5.0)\end{array}$ & $* * *$ & $\begin{array}{r}2.193 \\
(7.0)\end{array}$ & $* * *$ \\
\hline Immigration stock & $\begin{array}{r}-0.125 \\
(-0.9)\end{array}$ & $\begin{array}{r}0.117 \\
(0.7)\end{array}$ & $\begin{array}{r}-0.245 \\
(-2.3)\end{array}$ & $* *$ & $\begin{array}{r}-0.156 \\
(-1.4)\end{array}$ & \\
\hline$\Delta$ Immigration stock (5-year lag) & $\begin{array}{r}-0.013 \\
(-0.7)\end{array}$ & $\begin{array}{r}0.010 \\
(0.5)\end{array}$ & $\begin{array}{r}0.035 \\
(2.6)\end{array}$ & $* *$ & $\begin{array}{r}0.014 \\
(1.0)\end{array}$ & \\
\hline GDP per capita & $\begin{array}{l}-0.154 \quad * * * \\
(-6.5)\end{array}$ & $\begin{array}{r}-0.060 * * \\
(-2.1)\end{array}$ & $\begin{array}{r}-0.001 \\
(-0.1)\end{array}$ & & $\begin{array}{r}-0.104 \\
(-5.3)\end{array}$ & $* * *$ \\
\hline$\Delta$ GDP per capita (5-year lag) & $\begin{array}{rl}-0.205 & * * * \\
(-4.7) & \end{array}$ & $\begin{array}{r}-0.098 * \\
(-1.9)\end{array}$ & $\begin{array}{r}-0.035 \\
(-1.0)\end{array}$ & & $\begin{array}{r}-0.053 \\
(-1.5)\end{array}$ & \\
\hline Urban population & $\begin{array}{r}-0.200 \\
(-6.2)\end{array}$ & $\begin{array}{rl}-0.080 & * * \\
(-2.0) & \end{array}$ & $\begin{array}{r}-0.149 \\
(-5.9)\end{array}$ & $* * *$ & $\begin{array}{r}-0.129 \\
(-4.9)\end{array}$ & $* * *$ \\
\hline Intercept & $\begin{array}{c}0.998 \text { *** } \\
(9.8)\end{array}$ & $\begin{array}{r}0.586 \text { *** } \\
(4.8)\end{array}$ & $\begin{array}{r}0.554 \\
(6.9)\end{array}$ & $* * *$ & $\begin{array}{r}0.688 \\
(8.2)\end{array}$ & $* * *$ \\
\hline $\mathrm{R}^{2}$ & 0.742 & 0.317 & 0.454 & & 0.718 & \\
\hline Observations & 152 & 152 & 152 & & 152 & \\
\hline
\end{tabular}

Source SILC and ESS aggregated panel

Note: ${ }^{* * *},{ }^{* *},{ }^{*}$ statistically significant at the $1 \%, 5 \%$ and $10 \%$ level, respectively. 
Table 6. Authoritarianism, polarization and covariates by cohort. Within countries OLS

\begin{tabular}{|c|c|c|c|c|c|c|c|c|}
\hline \multirow{2}{*}{ RHS Variables } & \multirow{2}{*}{\multicolumn{2}{|c|}{ Full sample }} & \multicolumn{6}{|c|}{ Cohorts } \\
\hline & & & \multicolumn{2}{|c|}{$\begin{array}{c}\text { Born before } \\
1946\end{array}$} & \multicolumn{2}{|c|}{$\begin{array}{l}\text { Born between } \\
1946 \text { and } 1974\end{array}$} & \multicolumn{2}{|c|}{$\begin{array}{c}\text { Born after } \\
1974\end{array}$} \\
\hline Polarization index ${ }^{a}$ & $\begin{array}{r}0.595 \\
(2.5)\end{array}$ & & $\begin{array}{r}0.397 \\
(1.5)\end{array}$ & & $\begin{array}{r}0.481 \\
(2.0)\end{array}$ & & $\begin{array}{r}0.671 \\
(2.5)\end{array}$ & $* *$ \\
\hline Immigration stock & $\begin{array}{r}0.437 \\
(3.2)\end{array}$ & $* * *$ & $\begin{array}{r}0.176 \\
(1.1)\end{array}$ & & $\begin{array}{r}0.739 \\
(5.3)\end{array}$ & $* * *$ & $\begin{array}{r}0.753 \\
(3.9)\end{array}$ & $* * *$ \\
\hline$\Delta$ Immigration stock (5-year lag) & $\begin{array}{r}0.018 \\
(2.7)\end{array}$ & *** & $\begin{array}{r}0.010 \\
(1.2)\end{array}$ & & $\begin{array}{r}0.014 \\
(1.9)\end{array}$ & $*$ & $\begin{array}{r}0.019 \\
(2.0)\end{array}$ & * \\
\hline GDP per capita & $\begin{array}{r}-0.021 \\
(-1.1)\end{array}$ & & $\begin{array}{r}-0.053 \\
(-2.2)\end{array}$ & ** & $\begin{array}{r}0.010 \\
(0.5)\end{array}$ & & $\begin{array}{r}0.055 \\
(1.9)\end{array}$ & $*$ \\
\hline$\Delta$ GDP per capita (5-year lag) & $\begin{array}{r}-0.043 \\
(-2.9)\end{array}$ & $* * *$ & $\begin{array}{r}-0.060 \\
(-3.2)\end{array}$ & *** & $\begin{array}{r}-0.065 \\
(-4.0)\end{array}$ & $* * *$ & $\begin{array}{r}-0.063 \\
(-3.0)\end{array}$ & $* * *$ \\
\hline Urban population & $\begin{array}{r}-0.319 \\
(-3.7)\end{array}$ & $* * *$ & $\begin{array}{r}-0.183 \\
(-1.7)\end{array}$ & * & $\begin{array}{r}-0.278 \\
(-3.1)\end{array}$ & $* * *$ & $\begin{array}{r}-0.259 \\
(-2.1)\end{array}$ & $* *$ \\
\hline Intercept & $\begin{array}{r}0.617 \\
(7.9)\end{array}$ & $* * *$ & $\begin{array}{r}0.862 \\
(9.0)\end{array}$ & & $\begin{array}{r}0.497 \\
(6.0)\end{array}$ & & $\begin{array}{r}0.294 \\
(2.6)\end{array}$ & $* * *$ \\
\hline $\mathrm{R}^{2}$ & 0.941 & & 0.895 & & 0.948 & & 0.885 & \\
\hline No. of observations & 157 & & 156 & & 156 & & 156 & \\
\hline
\end{tabular}

Source: SILC and ESS aggregated panel.

Note: ${ }^{* * *},{ }^{* *},{ }^{*}$ statistically significant at the $1 \%, 5 \%$ and $10 \%$ level, respectively. Polarization index with $\delta=$ Ability to make ends meet and $\theta=1$. 
Appendix

Table A1. Matched ESS-SILC panel of European countries (data aggregated at country level)

\begin{tabular}{|c|l|c|c|c|c|c|c|c|c|c|}
\hline Region & Country & 2004 & 2006 & 2008 & 2010 & 2012 & 2014 & 2016 & 2018 & Total \\
\hline \multirow{5}{*}{ Central } & Austria & $\mathrm{X}$ & $\mathrm{X}$ & - & - & - & $\mathrm{X}$ & $\mathrm{X}$ & $\mathrm{X}$ & 5 \\
& Belgium & $\mathrm{X}$ & $\mathrm{X}$ & $\mathrm{X}$ & $\mathrm{X}$ & $\mathrm{X}$ & $\mathrm{X}$ & $\mathrm{X}$ & $\mathrm{X}$ & 8 \\
& France & - & $\mathrm{X}$ & $\mathrm{X}$ & $\mathrm{X}$ & $\mathrm{X}$ & $\mathrm{X}$ & $\mathrm{X}$ & $\mathrm{X}$ & 7 \\
& Germany & - & $\mathrm{X}$ & $\mathrm{X}$ & $\mathrm{X}$ & $\mathrm{X}$ & $\mathrm{X}$ & $\mathrm{X}$ & $\mathrm{X}$ & 7 \\
& Ireland & $\mathrm{X}$ & $\mathrm{X}$ & $\mathrm{X}$ & $\mathrm{X}$ & $\mathrm{X}$ & $\mathrm{X}$ & $\mathrm{X}$ & - & 7 \\
& Switzerland & - & - & $\mathrm{X}$ & $\mathrm{X}$ & $\mathrm{X}$ & $\mathrm{X}$ & $\mathrm{X}$ & $\mathrm{X}$ & 6 \\
& United Kingdom & - & $\mathrm{X}$ & $\mathrm{X}$ & $\mathrm{X}$ & $\mathrm{X}$ & $\mathrm{X}$ & $\mathrm{X}$ & - & 6 \\
\hline \multirow{5}{*}{ Southern } & Cyprus & - & $\mathrm{X}$ & $\mathrm{X}$ & $\mathrm{X}$ & $\mathrm{X}$ & - & - & $\mathrm{X}$ & 5 \\
& Greece & $\mathrm{X}$ & - & $\mathrm{X}$ & $\mathrm{X}$ & - & - & - & - & 3 \\
& Italy & - & - & - & - & $\mathrm{X}$ & - & $\mathrm{X}$ & $\mathrm{X}$ & 3 \\
& Portugal & $\mathrm{X}$ & $\mathrm{X}$ & $\mathrm{X}$ & $\mathrm{X}$ & $\mathrm{X}$ & $\mathrm{X}$ & $\mathrm{X}$ & $\mathrm{X}$ & 8 \\
& Spain & $\mathrm{X}$ & $\mathrm{X}$ & $\mathrm{X}$ & $\mathrm{X}$ & $\mathrm{X}$ & $\mathrm{X}$ & $\mathrm{X}$ & $\mathrm{X}$ & 8 \\
\hline \multirow{5}{*}{ Northern } & Denmark & $\mathrm{X}$ & $\mathrm{X}$ & $\mathrm{X}$ & $\mathrm{X}$ & $\mathrm{X}$ & $\mathrm{X}$ & - & - & 6 \\
& Finland & $\mathrm{X}$ & $\mathrm{X}$ & $\mathrm{X}$ & $\mathrm{X}$ & $\mathrm{X}$ & $\mathrm{X}$ & $\mathrm{X}$ & $\mathrm{X}$ & 8 \\
& Iceland & $\mathrm{X}$ & - & - & - & $\mathrm{X}$ & - & $\mathrm{X}$ & - & 3 \\
& Netherlands & - & $\mathrm{X}$ & $\mathrm{X}$ & $\mathrm{X}$ & $\mathrm{X}$ & $\mathrm{X}$ & $\mathrm{X}$ & $\mathrm{X}$ & 7 \\
& Norway & $\mathrm{X}$ & $\mathrm{X}$ & $\mathrm{X}$ & $\mathrm{X}$ & $\mathrm{X}$ & $\mathrm{X}$ & $\mathrm{X}$ & $\mathrm{X}$ & 8 \\
& Sweden & $\mathrm{X}$ & $\mathrm{X}$ & $\mathrm{X}$ & $\mathrm{X}$ & $\mathrm{X}$ & $\mathrm{X}$ & $\mathrm{X}$ & $\mathrm{X}$ & 8 \\
\hline \multirow{5}{*}{ Eastern } & Czechia & - & - & $\mathrm{X}$ & $\mathrm{X}$ & $\mathrm{X}$ & $\mathrm{X}$ & $\mathrm{X}$ & $\mathrm{X}$ & 6 \\
& Estonia & $\mathrm{X}$ & $\mathrm{X}$ & $\mathrm{X}$ & $\mathrm{X}$ & $\mathrm{X}$ & $\mathrm{X}$ & $\mathrm{X}$ & $\mathrm{X}$ & 8 \\
& Hungary & - & $\mathrm{X}$ & $\mathrm{X}$ & $\mathrm{X}$ & $\mathrm{X}$ & $\mathrm{X}$ & $\mathrm{X}$ & $\mathrm{X}$ & 7 \\
& Lithuania & - & - & - & $\mathrm{X}$ & $\mathrm{X}$ & $\mathrm{X}$ & $\mathrm{X}$ & $\mathrm{X}$ & 5 \\
& Poland & - & $\mathrm{X}$ & $\mathrm{X}$ & $\mathrm{X}$ & $\mathrm{X}$ & $\mathrm{X}$ & $\mathrm{X}$ & $\mathrm{X}$ & 7 \\
& Slovakia & - & $\mathrm{X}$ & $\mathrm{X}$ & $\mathrm{X}$ & $\mathrm{X}$ & - & - & - & 4 \\
& Slovenia & - & $\mathrm{X}$ & $\mathrm{X}$ & $\mathrm{X}$ & $\mathrm{X}$ & $\mathrm{X}$ & $\mathrm{X}$ & $\mathrm{X}$ & 7 \\
\hline \multirow{5}{*}{ Total } & & 12 & 19 & 21 & 22 & 23 & 20 & 21 & 19 & 157 \\
\hline
\end{tabular}


Table A3. Social values indicators built using selected ESS questions

\begin{tabular}{|c|c|c|}
\hline Indicator & Question asked & Scale \\
\hline $\begin{array}{l}\text { Distrust of } \\
\text { institutions }\end{array}$ & $\begin{array}{l}\text { Please tell me how much you personally trust each of the institutions: } \\
\text { 1. Country's parliament (trstprl) } \\
\text { 2. Political parties (trstprt) } \\
\text { 3. Politicians (trstplt) }\end{array}$ & $\begin{array}{l}0-10 \\
0-10 \\
0-10\end{array}$ \\
\hline Anti-immigration & $\begin{array}{l}\text { 1. Would you say it is generally bad or good for your country's economy that } \\
\text { people come to live here from other countries? (imbgeco) } \\
\text { 2. Would you say that your country's cultural life is generally undermined or } \\
\text { enriched by people coming to live here from other countries? (imueclt) } \\
\text { 3. Is your country made a worse or a better place to live by people coming to } \\
\text { live here from other countries? (imwbcht) }\end{array}$ & $\begin{array}{l}0-10 \\
0-10 \\
0-10\end{array}$ \\
\hline Authoritarianism & $\begin{array}{l}\text { Now I will briefly describe some people. Please listen to each description and } \\
\text { tell me how much each person is or is not like you: } \\
\text { 1. Important to behave properly (ipbhprp) } \\
\text { 2. Important to live in secure and safe surroundings (impsafe) } \\
\text { 3. Important that government is strong and ensures safety (ipstrgv) } \\
\text { 4. Important to follow traditions and customs (imptrad) } \\
\text { 5. Important to do what is told and follow rules (ipfrule) }\end{array}$ & $\begin{array}{l}1-6 \\
1-6 \\
1-6 \\
1-6 \\
1-6\end{array}$ \\
\hline Distrust of people & $\begin{array}{l}\text { 1. Generally speaking, would you say that most people can be trusted, or that } \\
\text { you can't be too careful in dealing with people? (ppltrst) } \\
\text { 2. Do you think that most people would try to take advantage of you if they } \\
\text { got the chance, or would they try to be fair? (pplfair) } \\
\text { 3. Would you say that most of the time people try to be helpful or that they } \\
\text { are mostly looking out for themselves? (pplhlp) }\end{array}$ & $\begin{array}{l}0-10 \\
0-10 \\
0-10\end{array}$ \\
\hline
\end{tabular}

Souce: ESS

Notes: Original ESS variables' acronyms between brackets. Each indicator is computed by summing up individuals' scores given to the corresponding questions. In each case, the sum is normalized between 0 to 1 . To compute the 'distrust of institutions' and 'anti-immigration' indicators, the original order of answers (0-10) reordered to (10-0), so that higher scores show higher mistrust in political institutions and higher anti-immigration attitudes, respectively. The 'Distrust of people' indicator is also known as 'generalized trust' in the literature (See Olivera, 2014). 
Table A2. Extreme right voting and abstentions. Percentages in the last election

\begin{tabular}{|c|c|c|c|c|c|c|c|}
\hline \multirow[t]{2}{*}{ Region } & \multirow[t]{2}{*}{ Country } & \multicolumn{3}{|c|}{$\begin{array}{l}\text { Vote for an extreme right-wing } \\
\text { party in last election }(\%)\end{array}$} & \multicolumn{3}{|c|}{$\begin{array}{c}\text { Did not vote } \\
\text { in last election }(\%)\end{array}$} \\
\hline & & 2004-08 & 2010-14 & 2016-18 & $2004-08$ & 2010-14 & 2016-18 \\
\hline \multirow{7}{*}{ Central } & Austria & 6.8 & 13.7 & 17.5 & 14.9 & 22.5 & 15.0 \\
\hline & Belgium & 9.9 & 3.8 & 2.7 & 8.7 & 11.3 & 9.7 \\
\hline & France & 6.1 & 11.4 & 13.7 & 23.9 & 28.3 & 33.7 \\
\hline & Germany & 1.3 & 2.6 & 6.6 & 20.5 & 18.4 & 15.4 \\
\hline & Ireland & 0.0 & 0.0 & 0.0 & 24.4 & 26.6 & 24.4 \\
\hline & Switzerland & 26.5 & 23.5 & 21.4 & 33.5 & 34.5 & 31.0 \\
\hline & United Kingdom & 0.0 & 7.1 & 5.4 & 30.0 & 31.5 & 22.1 \\
\hline \multirow{5}{*}{ Southern } & Cyprus & 0.0 & 0.0 & 0.6 & 7.5 & 20.4 & 28.5 \\
\hline & Greece & 46.3 & 29.9 & & 11.1 & 21.5 & \\
\hline & Italy & - & 1.7 & 15.1 & - & 20.3 & 22.1 \\
\hline & Portugal & 0.2 & 0.2 & 0.1 & 26.3 & 29.0 & 24.6 \\
\hline & Spain & 0.0 & 0.0 & 10.1 & 18.6 & 19.6 & 17.6 \\
\hline \multirow{6}{*}{ Northern } & Denmark & 9.3 & 11.8 & - & 8.4 & 8.3 & - \\
\hline & Finland & 2.1 & 11.9 & 13.8 & 18.6 & 18.5 & 16.3 \\
\hline & Iceland & 0.0 & 0.0 & 0.0 & 8.6 & 12.7 & 9.1 \\
\hline & Netherlands & 4.3 & 9.5 & 8.2 & 15.7 & 17.7 & 17.0 \\
\hline & Norway & 17.6 & 14.2 & 10.7 & 16.0 & 14.3 & 11.3 \\
\hline & Sweden & 0.0 & 4.5 & 4.5 & 9.9 & 8.3 & 6.1 \\
\hline \multirow{7}{*}{ Eastern } & Czechia & 0.0 & 20.8 & 33.8 & 43.9 & 37.1 & 37.7 \\
\hline & Estonia & 0.0 & 0.0 & 0.0 & 40.5 & 31.0 & 27.9 \\
\hline & Hungary & 0.8 & 12.4 & 12.6 & 23.0 & 27.7 & 26.0 \\
\hline & Lithuania & - & 0.0 & 0.0 & - & 43.5 & 39.1 \\
\hline & Poland & 29.5 & 34.3 & 52.1 & 32.2 & 29.3 & 26.8 \\
\hline & Slovakia & 8.3 & 11.8 & 16.3 & 28.3 & 27.3 & 31.3 \\
\hline & Slovenia & 39.4 & 30.6 & 29.3 & 27.9 & 30.3 & 30.4 \\
\hline
\end{tabular}

Source: ESS Rounds: 2, 3 \& 4 (2004, 2006 \& 2008); 5, 6 \& 7 (2010, 2012 \& 2014); 8 \& 9 (2016 \& 2018).

Notes: Countries without extreme right-wing vote coded in ESS over the period 2004-2018: Estonia, Iceland, Ireland and Lithuania. Extreme right-wing parties identified based on ESS documentation on Political Parties (ESS, 2020, Appendix A3) and on Chapel Hill Expert Survey (2014). Individuals not eligible to vote or with missing answer are excluded. 
Table A3. Social values indicators built using selected ESS questions

\begin{tabular}{|c|c|c|}
\hline Indicator & Question asked & Scale \\
\hline $\begin{array}{l}\text { Distrust of } \\
\text { institutions }\end{array}$ & $\begin{array}{l}\text { Please tell me how much you personally trust each of the institutions: } \\
\text { 4. Country's parliament (trstprl) } \\
\text { 5. Political parties (trstprt) } \\
\text { 6. Politicians (trstplt) }\end{array}$ & $\begin{array}{l}0-10 \\
0-10 \\
0-10\end{array}$ \\
\hline Anti-immigration & $\begin{array}{l}\text { 4. Would you say it is generally bad or good for your country's economy that } \\
\text { people come to live here from other countries? (imbgeco) } \\
\text { 5. Would you say that your country's cultural life is generally undermined or } \\
\text { enriched by people coming to live here from other countries? (imueclt) } \\
\text { 6. Is your country made a worse or a better place to live by people coming to } \\
\text { live here from other countries? (imwbcht) }\end{array}$ & $\begin{array}{l}0-10 \\
0-10 \\
0-10\end{array}$ \\
\hline Authoritarianism & $\begin{array}{l}\text { Now I will briefly describe some people. Please listen to each description and } \\
\text { tell me how much each person is or is not like you: } \\
\text { 6. Important to behave properly (ipbhprp) } \\
\text { 7. Important to live in secure and safe surroundings (impsafe) } \\
\text { 8. Important that government is strong and ensures safety (ipstrgv) } \\
\text { 9. Important to follow traditions and customs (imptrad) } \\
\text { 10.Important to do what is told and follow rules (ipfrule) }\end{array}$ & $\begin{array}{l}1-6 \\
1-6 \\
1-6 \\
1-6 \\
1-6\end{array}$ \\
\hline Distrust of people & $\begin{array}{l}\text { 4. Generally speaking, would you say that most people can be trusted, or that } \\
\text { you can't be too careful in dealing with people? (ppltrst) } \\
\text { 5. Do you think that most people would try to take advantage of you if they } \\
\text { got the chance, or would they try to be fair? (pplfair) } \\
\text { 6. Would you say that most of the time people try to be helpful or that they } \\
\text { are mostly looking out for themselves? (pplhlp) }\end{array}$ & $\begin{array}{l}0-10 \\
0-10 \\
0-10\end{array}$ \\
\hline
\end{tabular}

Source: ESS

Notes: Original ESS variables' acronyms between brackets. Each indicator is computed by summing up individuals' scores given to the corresponding questions. In each case, the sum is normalized between 0 to 1 . To compute the 'distrust of institutions' and 'anti-immigration' indicators, the original order of answers (0-10) was previously inversed (10-0), then higher scores indicate higher mistrust in political institutions and higher anti-immigration attitudes, respectively. 
Table A4. Material deprivation and subjective index

\begin{tabular}{|c|c|c|}
\hline Indicator & Question asked & Answer \\
\hline $\begin{array}{l}\text { Material } \\
\text { deprivation } \\
\text { index }\end{array}$ & $\begin{array}{l}\text { Looking at this card, can I just check whether your household could afford the } \\
\text { following? } \\
\text { - To pay for a week's annual holiday away from home? (HSO40) } \\
\text { - To eat meat, chicken or fish (or vegetarian equivalent) every second day? } \\
\quad \text { (HSO50) } \\
\text { - To pay an unexpected, but necessary, expense of 500€? (HSO60) } \\
\text { Do you have: } \\
\text { - a telephone? (HSO70) } \\
\text { - a colour TV? (HSO80) } \\
\text { - a computer? (HSO90) } \\
\text { - a wash machine? (HS100) } \\
\text { - a car? (HS110) } \\
\text { Can your household afford to keep its home adequately warm? (HH050) } \\
\text { Have you got either a bath or a shower for sole use of the household (HHO80) } \\
\text { Do you have an inside flushing toilet for sole use of the household? (HHO90) }\end{array}$ & $\begin{array}{l}0-1 \\
0-1 \\
0-1 \\
0-1 \\
0-1 \\
0-1 \\
0-1 \\
0-1\end{array}$ \\
\hline $\begin{array}{l}\text { Ability to } \\
\text { make ends } \\
\text { meet index }\end{array}$ & $\begin{array}{l}\text { A household may have different sources of income and more than one household } \\
\text { member may contribute to it. } \\
\text { Thinking of your household's total monthly or weekly income, is your household } \\
\text { able to make ends meet, that is pay your usual expenses.... (HS120) } \\
\text { - with great difficulty } \\
\text { - with difficulty } \\
\text { - with some difficulty } \\
\text { - fairly easily } \\
\text { - easily } \\
\text { - very easily }\end{array}$ & $\begin{array}{l}1 \\
2 \\
3 \\
4 \\
5 \\
6\end{array}$ \\
\hline
\end{tabular}

Source: SILC.

Notes: Original SILC variables' identification between brackets. The deprivation index is computed in two steps. First, we add the 11 binary binary answers to obtain a 0-11 scale. I a second step, we reorder this scale, so that the material deprivation index corresponds to the total number of negative answers to the list of questions. 
Table A5. Populist attitudes, polarization and covariates by cohort. OLS regressions

\begin{tabular}{|c|c|c|c|c|c|c|c|c|}
\hline & \multicolumn{2}{|c|}{$\begin{array}{l}\text { Distrust of } \\
\text { institutions }\end{array}$} & \multicolumn{2}{|c|}{ Anti-immigration } & \multicolumn{2}{|c|}{ Authoritarianism } & \multicolumn{2}{|c|}{$\begin{array}{l}\text { Distrust } \\
\text { of people }\end{array}$} \\
\hline \multicolumn{9}{|c|}{ Cohort: Born before 1946} \\
\hline Polarization index & $\begin{array}{r}0.847 \\
(2.575)\end{array}$ & ** & $\begin{array}{r}0.753 \\
(2.077)\end{array}$ & ** & $\begin{array}{r}0.949 \\
(3.945)\end{array}$ & $* * *$ & $\begin{array}{r}2.627 \\
(9.466)\end{array}$ & \\
\hline Immigration stock & $\begin{array}{r}-0.109 \\
(-0.758)\end{array}$ & & $\begin{array}{r}0.293 \\
(1.857)\end{array}$ & * & $\begin{array}{r}-0.130 \\
(-1.237)\end{array}$ & & $\begin{array}{r}-0.251 \\
(-2.074)\end{array}$ & ** \\
\hline$\Delta$ Immigration stock (5-year lag) & $\begin{array}{r}-0.042 \\
(-2.285)\end{array}$ & ** & $\begin{array}{r}-0.009 \\
(-0.464)\end{array}$ & & $\begin{array}{r}0.030 \\
(2.238)\end{array}$ & $* *$ & $\begin{array}{r}-0.016 \\
(-1.017)\end{array}$ & \\
\hline GDP per capita & $\begin{array}{r}-0.180 \\
(-7.061)\end{array}$ & *** & $\begin{array}{r}-0.107 \\
(-3.808)\end{array}$ & *** & $\begin{array}{r}-0.004 \\
(-0.219)\end{array}$ & & $\begin{array}{r}-0.094 \\
(-4.386)\end{array}$ & *** \\
\hline$\Delta$ GDP per capita (5-year lag) & $\begin{array}{r}-0.213 \\
(-4.588)\end{array}$ & *** & $\begin{array}{r}-0.107 \\
(-2.102)\end{array}$ & $* *$ & $\begin{array}{r}-0.033 \\
(-0.967)\end{array}$ & & $\begin{array}{r}-0.049 \\
(-1.252)\end{array}$ & \\
\hline Urban population & $\begin{array}{r}-0.110 \\
(-3.019)\end{array}$ & $* * *$ & $\begin{array}{r}-0.029 \\
(-0.720)\end{array}$ & & $\begin{array}{r}-0.091 \\
(-3.404)\end{array}$ & *** & $\begin{array}{r}-0.058 \\
(-1.879)\end{array}$ & $*$ \\
\hline Intercept & $\begin{array}{r}1.214 \\
(12.364)\end{array}$ & *** & $\begin{array}{r}0.863 \\
(7.977)\end{array}$ & $* * *$ & $\begin{array}{r}0.692 \\
(9.627)\end{array}$ & $* * *$ & $\begin{array}{r}0.716 \\
(8.644)\end{array}$ & *** \\
\hline $\mathrm{R}^{2}$ & 0.642 & & 0.327 & & 0.352 & & 0.753 & \\
\hline No. of observations & 156 & & 156 & & 156 & & 156 & \\
\hline \multicolumn{9}{|c|}{ Cohort: Born between 1946 and 1974} \\
\hline Polarization index & $\begin{array}{r}2.146 \\
(5.612)\end{array}$ & $* * *$ & $\begin{array}{r}2.122 \\
(4.734)\end{array}$ & *** & $\begin{array}{r}2.379 \\
(8.534)\end{array}$ & $* * *$ & $\begin{array}{r}2.864 \\
(9.994)\end{array}$ & *** \\
\hline Immigration stock & $\begin{array}{r}-0.012 \\
(-0.090)\end{array}$ & & $\begin{array}{r}0.231 \\
(1.458)\end{array}$ & & $\begin{array}{r}-0.207 \\
(-2.106)\end{array}$ & ** & $\begin{array}{r}-0.123 \\
(-1.213)\end{array}$ & \\
\hline$\Delta$ Immigration stock (5-year lag) & $\begin{array}{r}-0.015 \\
(-0.862)\end{array}$ & & $\begin{array}{r}0.008 \\
(0.377)\end{array}$ & & $\begin{array}{r}0.037 \\
(2.894)\end{array}$ & *** & $\begin{array}{r}0.017 \\
(1.258)\end{array}$ & \\
\hline GDP per capita & $\begin{array}{r}-0.151 \\
(-6.136)\end{array}$ & $* * *$ & $\begin{array}{r}-0.046 \\
(-1.596)\end{array}$ & & $\begin{array}{r}0.022 \\
(1.202)\end{array}$ & & $\begin{array}{r}-0.086 \\
(-4.644)\end{array}$ & *** \\
\hline$\Delta$ GDP per capita (5-year lag) & $\begin{array}{r}-0.168 \\
(-3.719)\end{array}$ & $* * *$ & $\begin{array}{r}-0.053 \\
(-1.007)\end{array}$ & & $\begin{array}{r}0.006 \\
(0.193)\end{array}$ & & $\begin{array}{r}0.007 \\
(0.198)\end{array}$ & \\
\hline Urban population & $\begin{array}{r}-0.177 \\
(-5.369)\end{array}$ & $* * *$ & $\begin{array}{r}-0.059 \\
(-1.535)\end{array}$ & & $\begin{array}{r}-0.135 \\
(-5.646)\end{array}$ & *** & $\begin{array}{r}-0.112 \\
(-4.534)\end{array}$ & *** \\
\hline Intercept & $\begin{array}{r}1.020 \\
(9.970)\end{array}$ & $* * *$ & $\begin{array}{r}0.521 \\
(4.344)\end{array}$ & *** & $\begin{array}{r}0.448 \\
(6.003)\end{array}$ & *** & $\begin{array}{r}0.616 \\
(8.033)\end{array}$ & *** \\
\hline $\mathrm{R}^{2}$ & 0.729 & & 0.374 & & 0.592 & & 0.783 & \\
\hline No. of observations & 157 & & 157 & & 157 & & 157 & \\
\hline \multicolumn{9}{|c|}{ Cohort: Born after 1974} \\
\hline Polarization index & $\begin{array}{r}2.198 \\
(6.718)\end{array}$ & *** & $\begin{array}{r}1.418 \\
(3.772)\end{array}$ & $* * *$ & $\begin{array}{r}1.744 \\
(6.912)\end{array}$ & *** & $\begin{array}{r}1.909 \\
(8.359)\end{array}$ & *** \\
\hline Immigration stock & $\begin{array}{r}0.090 \\
(0.676)\end{array}$ & & $\begin{array}{r}0.074 \\
(0.489)\end{array}$ & & $\begin{array}{r}-0.146 \\
(-1.430)\end{array}$ & & $\begin{array}{r}0.141 \\
(1.527)\end{array}$ & \\
\hline$\Delta$ Immigration stock (5-year lag) & $\begin{array}{r}0.004 \\
(0.216)\end{array}$ & & $\begin{array}{r}0.014 \\
(0.711)\end{array}$ & & $\begin{array}{r}0.026 \\
(1.947)\end{array}$ & $*$ & $\begin{array}{r}0.020 \\
(1.640)\end{array}$ & \\
\hline GDP per capita & $\begin{array}{r}-0.176 \\
(-8.257)\end{array}$ & $* * *$ & $\begin{array}{r}-0.044 \\
(-1.805)\end{array}$ & * & $\begin{array}{r}0.016 \\
(0.966)\end{array}$ & & $\begin{array}{r}-0.099 \\
(-6.636)\end{array}$ & $* * *$ \\
\hline$\Delta$ GDP per capita (5-year lag) & $\begin{array}{r}-0.148 \\
(-3.336)\end{array}$ & $* * *$ & $\begin{array}{r}-0.065 \\
(-1.268)\end{array}$ & & $\begin{array}{r}0.004 \\
(0.109)\end{array}$ & & $\begin{array}{r}0.013 \\
(0.432)\end{array}$ & \\
\hline Urban population & $\begin{array}{r}-0.251 \\
(-7.893)\end{array}$ & $* * *$ & $\begin{array}{r}-0.114 \\
(-3.128)\end{array}$ & *** & $\begin{array}{r}-0.157 \\
(-6.419)\end{array}$ & $* * *$ & $\begin{array}{r}-0.092 \\
(-4.161)\end{array}$ & *** \\
\hline Intercept & $\begin{array}{r}1.058 \\
(11.995)\end{array}$ & $* * *$ & $\begin{array}{r}0.523 \\
(5.162)\end{array}$ & *** & $\begin{array}{r}0.451 \\
(6.628)\end{array}$ & *** & $\begin{array}{r}0.693 \\
(11.260)\end{array}$ & *** \\
\hline $\mathrm{R}^{2}$ & 0.765 & & 0.296 & & 0.475 & & 0.702 & \\
\hline No. of observations & 157 & & 157 & & 157 & & 157 & \\
\hline
\end{tabular}

Source: SILC and ESS aggregated panel. Note: ${ }^{* * *},{ }^{* *},{ }^{*}$ statistically significant at the $1 \%, 5 \%$ and $10 \%$ level, respectively. 